\title{
Analysis of Water Treatment by Moringa oleifera Bioflocculant Prepared Via Supercritical Fluid Extraction
}

\author{
Muhammad Azroie Mohamed Yusoff ${ }^{1,3}$, Choon Weng Lee ${ }^{1,2 *}$, Chui Wei Bong, \\ ${ }^{1}$ Laboratory of Microbial Ecology, Institute of Biological Sciences, Faculty of Science, \\ University of Malaya, Kuala Lumpur, Malaysia \\ ${ }^{2}$ Institute of Ocean and Earth Sciences, University of Malaya, Kuala Lumpur, Malaysia \\ ${ }^{3}$ National Hydraulic Research Institute of Malaysia, Selangor, Malaysia
}

Received: 26 December 2017

Accepted: 10 June 2018

\begin{abstract}
In this study, we used supercritical fluid extraction to prepare Moringa oleifera as a bioflocculant and studied its efficacy in water treatment. Relative to the conventional solvent extraction method, supercritical fluid extraction produced $42 \%$ more bioflocculant and was a more efficient method with both time (about seven hours less) and cost savings (about USD30 less). The bioflocculant produced via supercritical fluid extraction was also smaller $(18 \pm 5 \mu \mathrm{m})$ and more similar in size (Coefficient of Variation, $\mathrm{CV}=28 \%)$ as opposed to conventional solvent extraction $(23 \pm 8 \mu \mathrm{m}, \mathrm{CV}=35 \%)$. It was able to reduce more than $95 \%$ of turbidity and up to $60 \%$ bacterial population. Its performance in reducing selected heavy metals from water samples was also generally better than aluminium sulfate or alum. Our study showed that with the exception of cost restrictions, M. oleifera bioflocculant produced via supercritical fluid extraction has the potential to replace alum in water treatment plants.
\end{abstract}

Keywords: Moringa oleifera; bioflocculant; water treatment; supercritical fluid extraction

\section{Introduction}

In a water treatment plant the flocculation step is the main process for turbidity removal. Currently, the flocculation step is carried out with various types of chemical flocculants, e.g., aluminium sulfate or its variants [1]. However, studies have suggested that there may be negative health implications of using alum, such as Alzheimer's disease [2]. Even though it is difficult

*e-mail: lee@um.edu.my to show a causal relationship through epidemiological studies, the long-term effects of aluminium cannot be dismissed, and there is a need to control exposure to aluminium in the general population [3]. Other than health implications, another disadvantage to using alum in a water treatment plant is the large sludge volume produced [4] and the high cost of disposing of alum sludge as scheduled waste.

With the growing global population, world water demand has increased seven-fold in the last century and is expected to increase further with the economic expansion of developing countries [1]. Existing freshwater resources need protection and 
new water resources must be developed in order to meet the world's growing demand. This will require better water treatment technology. Therefore, any improvement available for the water treatment process is of importance. Alternative technologies (e.g., membrane) are favored over other technologies for water treatment such as disinfection, distillation, or media filtration because, in principle, they require no chemical additives, thermal inputs, or regeneration of spent media [1]. Another alternative adopts the use of natural flocculants or bioflocculants for turbidity removal in the water treatment process. In this context, Plantago spp., common bean seed, chestnut, acorn seed, Opuntia spp., chitosan, ipomoea seeds, Cactus latifaria, Cassia obtusifolia, and Sterculia lychnophora have been presented as viable alternatives [5].

A potential bioflocculant investigated in this study is from Moringa oleifera seeds [6]. The active component derived from both crushed (powdered) and defatted (oil extracted) seeds of $M$. oleifera is a soluble protein that contains a natural cationic polyelectrolyte that causes flocculation [7]. The conventional method to strip fat from $M$. oleifera seeds involves solvent extraction (SE) using n-hexane [8]. However Ruttarattanamongkol et al. [9] recently proposed using supercritical fluid extraction (SFE) to extract oil from $M$. oleifera. SFE uses highpressure carbon dioxide $\left(\mathrm{CO}_{2}\right)$ as an oil extracting agent and has proven an excellent alternative to chemical solvents [9]. The use of SFE in extraction also eliminates organic solvents and the expensive post-processing step of solvent removal [10].

Although the use of SFE to extract oil from $M$. oleifera has been reported [9], the potential use of M. oleifera as bioflocculant after SFE has not been assessed. There is also limited published data to evaluate the effectiveness of $M$. oleifera coagulant versus the conventional alum [11]. Therefore, in this study we investigated the potential of M. oleifera bioflocculant in water treatment after SFE extraction. We also reported the optimal water treatment conditions by $M$. oleifera bioflocculant in terms of water turbidity and bacterial population and heavy metal removal.

\section{Experimental}

Preparation of $M$. oleifera Seeds as Bioflocculant

M. oleifera was obtained from the state of Sabah in Malaysia. We used only good-quality seeds from dry pods. The seeds were removed from their shells and the kernels were blended into medium fine powder using a domestic blender. The powder was then oven dried at $50^{\circ} \mathrm{C}$ overnight (Memmert, Germany) to decrease its moisture content (Fig. 1). We then extracted the oil inside the $M$. oleifera powder via the SFE method [12] using a TST Oven Extraction system (OV-SCF-1000, Taiwan). Briefly, the extraction was carried out at $250 \mathrm{Bar}$ and 50 to $60^{\circ} \mathrm{C}$ with $10 \mathrm{~min}$ of

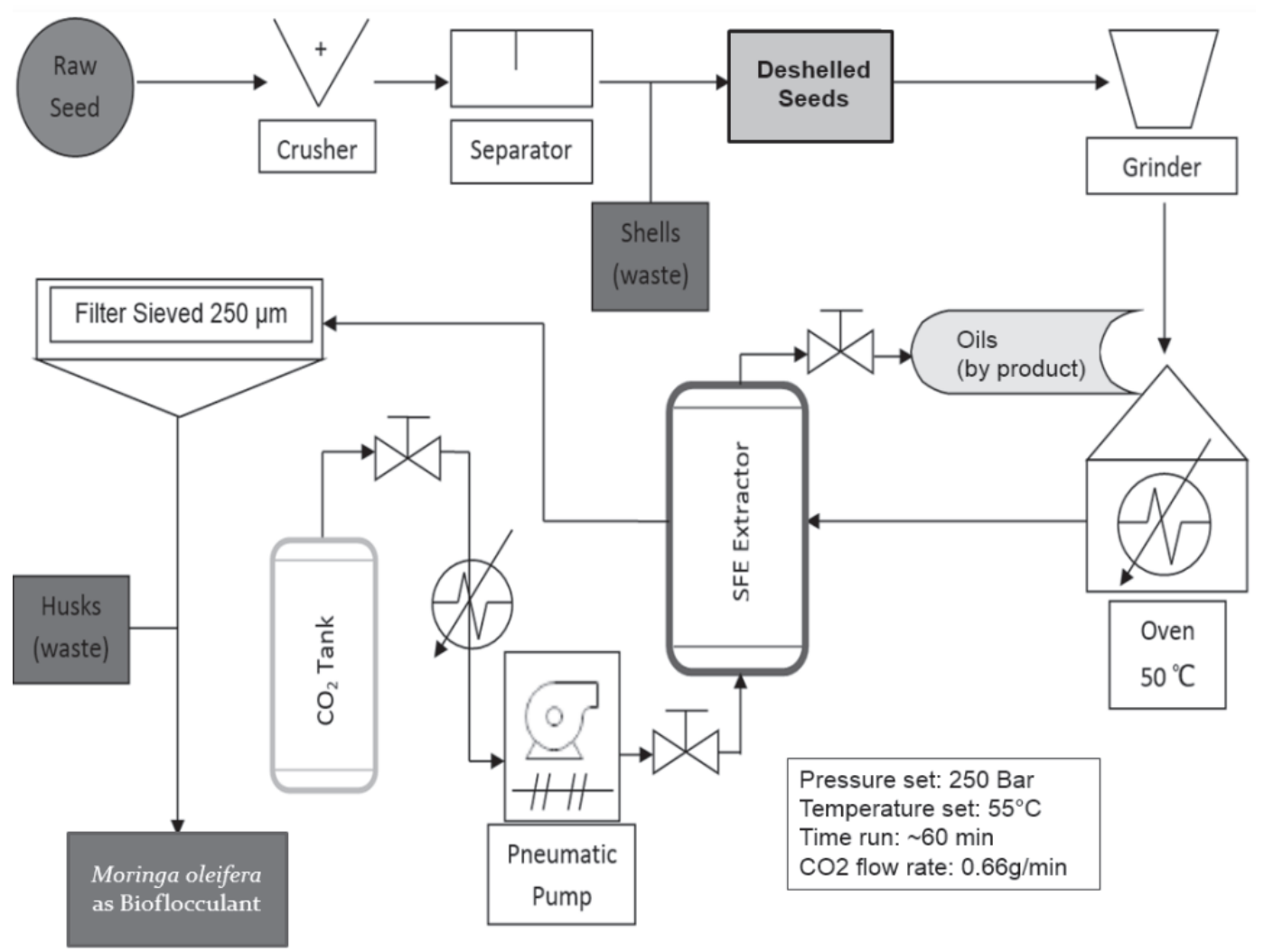

Fig. 1. Flow diagram showing the steps in the preparation of M. oleifera bioflocculant. 
Table 1. Comparison of reagents and utility costs incurred in producing oil-extracted $M$. oleifera bioflocculant via solvent extraction (SE) and supercritical fluid extraction (SFE). The Malaysian Electricity Tariff is MYR 0.218 ( USD 0.05) for the first $200 \mathrm{kWh}$. Estimated price in USD based on a MYR4-to-USD1 conversion rate.

\begin{tabular}{|c|c|c|}
\hline & Solvent Extraction (SE) & Supercritical Fluid Extraction (SFE) \\
\hline Extraction agent & n-Hexane 99\% & Carbon Dioxide $\left(\mathrm{CO}_{2}\right) 99 \%$ \\
\hline Average local price $\mathrm{L}^{-1}$ & USD $12.50 \mathrm{~L}^{-1}$ & $\begin{array}{c}\text { USD } 0.66 \mathrm{~L}^{-1}+\text { USD } 0.01 \mathrm{~L}^{-1} \\
\left(\mathrm{~N}_{2} \text { gas for flushing) }\right.\end{array}$ \\
\hline Usage to produce for $1 \mathrm{~kg}$ bioflocculant & $6 \mathrm{~L}$ n-Hexane & $68.29 \mathrm{~L} \mathrm{CO}_{2}$ \\
\hline Reagent total cost usage for $1 \mathrm{~kg}$ & USD 75.00 & USD 45.75 \\
\hline Extracting instrument & $\begin{array}{c}\text { Hanon SOX406 Fat } \\
\text { Analyzer }\end{array}$ & TST OV-SCF-10000 Extraction Oven \\
\hline Electricity power usage & 1 Kilowatt (kW) & $1.76 \mathrm{~kW}$ \\
\hline Extraction time for $1 \mathrm{~kg}$ bioflocculant & 9 hours & 2 hours \\
\hline Electricity Cost usage & USD $0.05 \mathrm{~h}^{-1}$ & USD $0.09 \mathrm{~h}^{-1}$ \\
\hline Total Electricity Cost usage & USD 0.45 & USD 0.18 \\
\hline Reagent and Utilities Cost for $1 \mathrm{~kg}$ bioflocculant produced & USD 75.45 & USD 45.93 \\
\hline M. oleifera cost for $1 \mathrm{~kg}$ produced (local price) & USD 11.00 & USD 11.00 \\
\hline Grand total for $1 \mathrm{~kg}$ bioflocculant produced & USD 86.45 & USD 56.93 \\
\hline
\end{tabular}

static extraction and 30 min of dynamic extraction with an industrial-grade $\mathrm{CO}_{2}$ flow rate of $0.66 \mathrm{~g} \mathrm{~min}^{-1}$. The final product was sieved through a $250 \mu \mathrm{m}$ mesh to remove any remaining husk.

\section{Jar Test}

Jar testing simulates the flocculation process with treatment chemicals in a water treatment plant and helps determine the right amount of treatment chemicals to improve the plant's performance. We collected river water using a sterile 50-liter high-density poly-ethylene plastic container at the Labu River water intake point at Sungai Labu Water Treatment Plant, Salak Tinggi $\left(2^{\circ} \mathrm{N} 47^{\prime} 21^{\prime \prime}, 101^{\circ} \mathrm{E} 44^{\prime} 15^{\prime \prime}\right)$, and kept it cold at $4^{\circ} \mathrm{C}$ until analysis. Turbidity, $\mathrm{pH}$, total suspended solids (TSS) and heavy metals - aluminium (Al), barium (Ba), chromium $(\mathrm{Cr})$, cuprum $(\mathrm{Cu})$, ferum $(\mathrm{Fe})$, manganese $(\mathrm{Mn})$, nickel $(\mathrm{Ni})$, plumbum $(\mathrm{Pb})$, and zinc $(\mathrm{Zn})$ - were analyzed according to APHA guidelines [13]. Turbidity was measured using a turbidimeter (Thermo, USA), whereas $\mathrm{pH}$ and TSS were measured by a handheld pH meter (Mettler Toledo, Spain) and a UV-visible spectrophotometer (DR 5000 Hach, USA), respectively. Heavy metal analyses were by inductive coupled plasma or ICP-OES (Perkin Elmer, USA), with detection limits within the SEMI C10-1109 guidelines. We also enumerated culturable heterotrophic microflora on four different types of microbiological media (Reasoner's 2 agar (R2A), Tryptone Glucose Yeast agar (TGYA), Casitone Glycerol Yeast Autolysate agar (CGYA) and MacConkey Agar) via the spread plate method. MacConkey agar was used for the enumeration of fecal pollution indicators such as coliform. All plates were incubated aerobically at $35^{\circ} \mathrm{C}$ overnight. Microbiological counts were also carried out according to standard APHA guidelines.

Table 2. Before and after comparison of (A) turbidity in NTU and (B) total suspended solids (TSS, $\mathrm{mg} \mathrm{L}^{-1}$ ) in jar test analyses at various dosages (10-1000 $\left.\mathrm{mg} \mathrm{L}^{-1}\right)$ of M. oleifera bioflocculant versus the control alum $\left(25 \mathrm{mg} \mathrm{L}^{-1}\right)$.

\begin{tabular}{|c|c|c|c|}
\hline \multirow{2}{*}{$\begin{array}{c}\text { Dosage }\left(\mathrm{mg} \mathrm{L}^{-1}\right) \\
\text { M. oleifera }\end{array}$} & \multicolumn{2}{|c|}{ A. Turbidity (NTU) } & \multirow{2}{*}{ \% Reduction } \\
\hline & Before & After & \\
\hline 1000 & $853 \pm 2$ & $43 \pm 1$ & 95.0 \\
\hline 500 & $834 \pm 5$ & $31 \pm 3$ & 96.2 \\
\hline 100 & $821 \pm 4$ & $24 \pm 1$ & 97.0 \\
\hline 50 & $835 \pm 2$ & $21 \pm 2$ & 97.5 \\
\hline 10 & $712 \pm 4$ & $10 \pm 1$ & 98.6 \\
\hline \multicolumn{4}{|c|}{ Alum } \\
\hline 25 & $919 \pm 3$ & $6 \pm 1$ & 99.3 \\
\hline \multirow{2}{*}{$\begin{array}{c}\text { Dosage }\left(\mathrm{mg} \mathrm{L}^{-1}\right) \\
\text { M. oleifera }\end{array}$} & \multicolumn{2}{|c|}{ B. TSS $\left(\mathrm{mg} \mathrm{L}^{-1}\right)$} & \multirow{2}{*}{$\%$ Reduction } \\
\hline & Before & After & \\
\hline 1000 & $2907 \pm 4$ & $147 \pm 3$ & 94.9 \\
\hline 500 & $2846 \pm 5$ & $87 \pm 1$ & 96.9 \\
\hline 100 & $2811 \pm 2$ & $82 \pm 4$ & 97.1 \\
\hline 50 & $2863 \pm 7$ & $61 \pm 5$ & 97.9 \\
\hline 10 & $2452 \pm 3$ & $33 \pm 2$ & 98.7 \\
\hline \multicolumn{4}{|c|}{ Alum } \\
\hline 25 & $3153 \pm 7$ & $20 \pm 1$ & 99.4 \\
\hline
\end{tabular}


Table 3. Comparison of heavy metal removal by alum and M. oleifera bioflocculant from supercritical fluid extraction (SFE). Instrument detection limits ( $\left.\mu \mathrm{g} \mathrm{L}^{-1}\right)$ : $\mathrm{Al}$ (1.86), $\mathrm{Ba}(0.529), \mathrm{Cr}(0.838), \mathrm{Cu}(0.953), \mathrm{Fe}(0.736), \mathrm{Mn}(0.176), \mathrm{Ni}(1.22), \mathrm{Pb}(8.56)$, and $\mathrm{Zn}(0.527)$.

\begin{tabular}{|c|c|c|c|c|}
\hline Metal & $\begin{array}{l}\text { Type of coagulant and dosage } \\
\qquad\left(\mathrm{mg} \mathrm{L}^{-1}\right)\end{array}$ & $\begin{array}{l}\text { Initial metal concentration at } 0 \mathrm{~min} \\
\qquad\left(\mathrm{mg} \mathrm{L}^{-1}\right)\end{array}$ & $\begin{array}{l}\text { Final metal concentration at } \\
15 \mathrm{~min}\left(\mathrm{mg} \mathrm{L}^{-1}\right)\end{array}$ & $\begin{array}{l}\mathrm{p} \text {-value } \\
\text { (t-test) }\end{array}$ \\
\hline \multirow{2}{*}{$\mathrm{Al}$} & SFE (10) & $19.62 \pm 1.74$ & $0.11 \pm 0.02$ & $1.6 \times 10^{-54}$ \\
\hline & Alum (25) & & $0.15 \pm 0.02$ & $1.8 \times 10^{-54}$ \\
\hline \multirow{2}{*}{$\mathrm{Ba}$} & SFE (10) & $0.16 \pm 0.02$ & $0.01 \pm 0.00$ & $1.2 \times 10^{-49}$ \\
\hline & Alum (25) & & $0.02 \pm 0.00$ & $1.9 \times 10^{-48}$ \\
\hline \multirow{2}{*}{$\mathrm{Cr}$} & SFE (10) & $0.02 \pm 0.00$ & ND & $9.4 \times 10^{-41}$ \\
\hline & Alum (25) & & ND & $4.6 \times 10^{-40}$ \\
\hline \multirow{2}{*}{$\mathrm{Cu}$} & SFE (10) & $0.05 \pm 0.04$ & ND & $1.1 \times 10^{-7}$ \\
\hline & Alum (25) & & ND & $7.5 \times 10^{-8}$ \\
\hline \multirow{2}{*}{$\mathrm{Fe}$} & SFE (10) & $47.73 \pm 6.91$ & $0.19 \pm 0.1$ & $1.8 \times 10^{-42}$ \\
\hline & Alum (25) & & $0.1 \pm 0.02$ & $1.6 \times 10^{-42}$ \\
\hline \multirow{2}{*}{$\mathrm{Mn}$} & SFE (10) & $0.73 \pm 0.05$ & $0.02 \pm 0.01$ & $2.4 \times 10^{-57}$ \\
\hline & Alum (25) & & $0.04 \pm 0.01$ & $1.4 \times 10^{-56}$ \\
\hline \multirow{2}{*}{$\mathrm{Ni}$} & SFE (10) & $0.02 \pm 0.04$ & ND & $6.4 \times 10^{-6}$ \\
\hline & Alum (25) & & ND & $2.6 \times 10^{-6}$ \\
\hline \multirow{2}{*}{$\mathrm{Pb}$} & SFE (10) & $0.08 \pm 0.01$ & ND & $4.4 \times 10^{-29}$ \\
\hline & Alum (25) & & ND & $3.2 \times 10^{-56}$ \\
\hline \multirow{2}{*}{$\mathrm{Zn}$} & SFE (10) & $0.39 \pm 0.1$ & ND & $1.2 \times 10^{-31}$ \\
\hline & Alum (25) & & ND & $7.2 \times 10^{-25}$ \\
\hline
\end{tabular}

We carried out the jar test analysis using a jar tester (Lovibond Flocculator, Germany) according to standard sedimentation jar test analysis, where for each test run a one-liter test solution was mixed at $200 \mathrm{rpm}$ for $5 \mathrm{~min}$ and sedimentation was for $15 \mathrm{~min}$. For each jar test assay, M. oleifera bioflocculant at different treatment dosages were carried out against the control alum, and selected parameters (turbidity, TSS, culturable bacteria, and heavy metal concentration) before and after each jar test analysis were recorded. All values were reported as mean \pm standard deviation (S.D.) unless otherwise stated. Count data were log-transformed before statistical analyses to meet parametric assumptions of equality of variance and normal distribution. Analysis of variance and Tukey's test were used to test the significance of the reduction of selected parameters after flocculation.

\section{Results and Discussion}

\section{Preparation of $M$. oleifera as Bioflocculant}

In this study, the yield of $M$. oleifera bioflocculant extracted via SFE technique was $42.1 \pm 0.1 \%$ of the initial weight and is comparable to the yield reported by Palafox et al. [14]. The yield from SFE was higher than the conventional SE method using n-hexane as a solvent $(\mathrm{t}=9.79, \mathrm{p}<0.001)$. The amount of oil extracted using the SFE method was also higher than the SE method $(\mathrm{t}=4.56, \mathrm{p}<0.05)$. Concurrently, less husk was produced from the SFE method, i.e., about $28.3 \pm 0.2 \%$ of initial weight as compared to $33.0 \pm 0.3 \%$ from the SE method $(\mathrm{t}=10.58, \mathrm{p}<0.001)$. Using the SFE method, we produced about $420 \mathrm{~g} \mathrm{~kg}^{-1}$ (initial weight) of pure M. oleifera bioflocculant, $300 \mathrm{~g} \mathrm{~kg}^{-1}$ of extracted oil, and $280 \mathrm{~g} \mathrm{~kg}^{-1}$ husk waste. The diameter of particles via SFE method ranged from 10 to $35 \mu \mathrm{m}(18 \pm 5 \mu \mathrm{m}$, $\mathrm{n}=110)$ and were smaller than via the SE method $(11-39 \mu \mathrm{m}, 23 \pm 8 \mu \mathrm{m}, \mathrm{n}=110)\left(\mathrm{t}=5.185, \mathrm{p}=1 \times 10^{-6}\right)$. This was probably due to the high pressure (250 bar) applied during the SFE extraction process, which is known to result in smaller-sized particles [15]. In contrast, the SE method was significantly less efficient in extracting oil from $M$. oleifera, and the bioflocculant particles formed were larger and visibly not uniform. The more efficient oil extraction via SFE method is of a great advantage as it also reduced the organic load from the seeds. The reduced organic load can help overcome the problem of increased organic load, water colour, taste, and odour in water treatment when using M. oleifera bioflocculant [16].

From the estimated cost to produce one $\mathrm{kg}$ of bioflocculant, we showed that the SFE method was 
about USD30 cheaper than the SE method (Table 1). Extraction via SE method also took up more time (nine hours) than via SFE method (two hours). Moreover, the $M$. oleifera bioflocculant after solvent extraction is readily contaminated with solvent [8], which is toxic and harmful to the environment [17]. Consequently, additional processing steps in the SE extraction system had to be implemented to eliminate chemical residue [14]. Although this is usually done via a series of distillation units under vacuum and other ancillary apparatus (such as a deodorizer and degumming [18]), these additional processing steps would have incurred extra cost and time. We showed that extraction via SFE was a viable and better method with both time and cost savings relative to the SE method.

\section{Jar Test Analysis}

In the jar test analyses, the effectiveness of $M$. oleifera bioflocculant from the SFE method as a flocculating agent for water treatment was compared with alum, which is the common coagulant used in conventional water treatment. The average turbidity of the raw water sample for each assay ranged from 712 to 919 NTU (nephelometric turbidity unit) and was highly turbid. The amount of $M$. oleifera bioflocculant used in the jar test analysis ranged from $10 \mathrm{mg} \mathrm{L}^{-1}$ to $1000 \mathrm{mg} \mathrm{L}^{-1}$, and the turbidity of the raw water was reduced by $95.0 \%$ to $98.6 \%(\mathrm{~F}=168.7$, $\left.\mathrm{df}=5, \mathrm{p}=1.096 \times 10^{-10}\right)$ (Table 2). This level of reduction, however, was still lower than alum, which reduced water turbidity by $99.3 \%$ ( $\mathrm{q}>6.53, \mathrm{p}<0.0061$ ). Similarly, M. oleifera bioflocculant reduced TSS by $94.9 \%$ to $98.7 \%\left(\mathrm{~F}=661.1, \mathrm{df}=5, \mathrm{p}=3.27 \times 10^{-14}\right)$, which was less than the reduction achieved by alum (99.4\%) $(\mathrm{q}>11.50, \mathrm{p}<0.0002)$.

With the $M$. oleifera bioflocculant we were able to achieve at least $95 \%$ reduction in turbidity and TSS. The highest reduction was obtained with $10 \mathrm{mg} \mathrm{L}^{-1}$ dosage, at which turbidity and TSS were reduced by $98 \%$. The SFE extracted $M$. oleifera bioflocculant performed strikingly better than when using filtered ground seed suspension, i.e., about $94 \%$ turbidity reduction at $400 \mathrm{mg} \mathrm{L}^{-1}$ dosage [19]. Our results were also clearly better than when using $M$. oleifera bioflocculant extracted with ether, which reduced turbidity by $90 \%$ at $500 \mathrm{mg} \mathrm{L}^{-1}$ [16]. Our results showed vast improvement in the reduction of turbidity and TSS relative to previous extraction methods [20, 21], and suggested the viability of SFEextracted $M$. oleifera bioflocculant as a replacement for alum in water treatment.

Table 3 shows the heavy metal removal by M. oleifera bioflocculant from SFE and alum in a jar test analysis at the optimum dosage of $10 \mathrm{mg} \mathrm{L}^{-1}$ for $M$. oleifera bioflocculant and $25 \mathrm{mg} \mathrm{L}^{-1}$ for alum. Both bioflocculant and alum significantly reduced the concentration of the tested heavy metal. Tests showed that both bioflocculant and alum removed $\mathrm{Cr}, \mathrm{Cu}, \mathrm{Ni}$, $\mathrm{Pb}$, and $\mathrm{Zn}$ to non-detectable or below the detection
Table 4. Culturable bacterial count on R2A, CGYA, TGYA, and MacConkey Agar in jar test analyses before and after treatment with varying dosages of $M$. oleifera bioflocculant and alum.

\begin{tabular}{|c|c|c|c|}
\hline \multirow{3}{*}{$\begin{array}{l}\text { Type of Dosage } \\
\text { (M. oleifera or } \\
\text { alum) in } \mathrm{mg} \mathrm{L}^{-1}\end{array}$} & \multirow{2}{*}{\multicolumn{2}{|c|}{$\frac{\text { Media }}{\text { R2A }\left(\text { cfu ml }^{-1}\right)}$}} & \multirow{3}{*}{$\begin{array}{c}\% \\
\text { Reduction }\end{array}$} \\
\hline & & & \\
\hline & Before & After & \\
\hline M. oleifera 1000 & $7.7 \pm 0.6 \times 10^{4}$ & $2.9 \pm 0.9 \times 10^{4}$ & 61.6 \\
\hline M. oleifera 500 & $7.4 \pm 0.5 \times 10^{4}$ & $3.2 \pm 0.8 \times 10^{4}$ & 57.1 \\
\hline M. oleifera 100 & $7.4 \pm 0.6 \times 10^{4}$ & $3.9 \pm 1.7 \times 10^{4}$ & 47.2 \\
\hline M. oleifera 50 & $7.3 \pm 0.6 \times 10^{4}$ & $3.3 \pm 0.7 \times 10^{4}$ & 55.7 \\
\hline M. oleifera 10 & $7.6 \pm 0.9 \times 10^{4}$ & $3.4 \pm 0.9 \times 10^{4}$ & 54.9 \\
\hline \multirow[t]{3}{*}{ Alum 25} & $7.6 \pm 0.5 \times 10^{4}$ & $5.9 \pm 1.8 \times 10^{2}$ & 99.2 \\
\hline & \multicolumn{2}{|c|}{ CGYA (cfu ml-1) } & \\
\hline & Before & After & \\
\hline M. oleifera 1000 & $2.4 \pm 0.5 \times 10^{4}$ & $1.0 \pm 0.4 \times 10^{4}$ & 59.4 \\
\hline M. oleifera 500 & $2.5 \pm 0.4 \times 10^{4}$ & $1.0 \pm 0.5 \times 10^{4}$ & 59.7 \\
\hline M. oleifera 100 & $2.6 \pm 0.5 \times 10^{4}$ & $1.0 \pm 0.4 \times 10^{4}$ & 62.2 \\
\hline M. oleifera 50 & $2.5 \pm 0.2 \times 10^{4}$ & $1.1 \pm 0.6 \times 10^{4}$ & 57.6 \\
\hline M. oleifera 10 & $2.5 \pm 0.3 \times 10^{4}$ & $1.1 \pm 0.5 \times 10^{4}$ & 56.3 \\
\hline \multirow[t]{3}{*}{ Alum 25} & $2.3 \pm 0.5 \times 10^{4}$ & $9.7 \pm 1.4 \times 10^{1}$ & 99.6 \\
\hline & \multicolumn{2}{|c|}{ TGYA $\left(\mathrm{cfu} \mathrm{ml} \mathbf{l}^{-1}\right)$} & \\
\hline & Before & After & \\
\hline M. oleifera 1000 & $6.5 \pm 0.3 \times 10^{4}$ & $3.0 \pm 0.9 \times 10^{4}$ & 53.4 \\
\hline M. oleifera 500 & $6.6 \pm 0.5 \times 10^{4}$ & $2.9 \pm 0.8 \times 10^{4}$ & 55.3 \\
\hline M. oleifera 100 & $6.8 \pm 0.4 \times 10^{4}$ & $3.0 \pm 0.9 \times 10^{4}$ & 56.0 \\
\hline M. oleifera 50 & $6.4 \pm 0.3 \times 10^{4}$ & $3.0 \pm 0.9 \times 10^{4}$ & 52.1 \\
\hline M. oleifera 10 & $6.3 \pm 0.3 \times 10^{4}$ & $3.3 \pm 0.9 \times 10^{4}$ & 47.4 \\
\hline \multirow[t]{3}{*}{ Alum 25} & $6.4 \pm 0.2 \times 10^{4}$ & $3.3 \pm 1.4 \times 10^{2}$ & 99.5 \\
\hline & \multicolumn{2}{|c|}{ MacConkey Agar $\left(\mathrm{cfu} \mathrm{ml}{ }^{-1}\right)$} & \\
\hline & Before & After & \\
\hline M. oleifera 1000 & $6.4 \pm 0.3 \times 10^{4}$ & $2.9 \pm 0.7 \times 10^{4}$ & 53.4 \\
\hline M. oleifera 500 & $6.1 \pm 0.4 \times 10^{4}$ & $3.4 \pm 0.7 \times 10^{4}$ & 43.8 \\
\hline M. oleifera 100 & $6.5 \pm 0.3 \times 10^{4}$ & $3.3 \pm 0.7 \times 10^{4}$ & 49.2 \\
\hline M. oleifera 50 & $6.4 \pm 0.3 \times 10^{4}$ & $3.1 \pm 0.8 \times 10^{4}$ & 51.6 \\
\hline M. oleifera 10 & $6.2 \pm 0.2 \times 10^{4}$ & $2.9 \pm 0.6 \times 10^{4}$ & 53.3 \\
\hline Alum 25 & $6.6 \pm 0.3 \times 10^{4}$ & $5.7 \pm 1.6 \times 10^{2}$ & 99.1 \\
\hline
\end{tabular}

limit of the analytical instrument. For $\mathrm{Al}, \mathrm{Ba}$, and $\mathrm{Mn}, M$. oleifera bioflocculant also reduced the heavy metal concentration, but at a higher degree than alum. The only exception was $\mathrm{Fe}$, where alum reduced $\mathrm{Fe}$ concentration at a higher degree than $M$. oleifera bioflocculant. The bioflocculant generally performed better than alum in removing heavy metals, and could 
Table 5. Estimated cost of conventional water treatment system using alum as coagulant versus $M$. oleifera bioflocculant. *Estimated price in USD based on Kualiti Alam Ltd (a local scheduled waste handling company). MLD = million liter day ${ }^{-1}$, MT $=$ metric ton, $\mathrm{WTP}=$ water treatment plant.

\begin{tabular}{|c|c|c|}
\hline & Alum coagulant & M. oleifera bioflocculant \\
\hline Origin & Aluminium sulfate & M. oleifera \\
\hline Average local price $\mathrm{kg}^{-1}$ & $<$ USD $0.08 \mathrm{~kg}^{-1}$ & USD $11.00 \mathrm{~kg}^{-1}$ \\
\hline Routine treatment dosage & $\begin{array}{l}25 \mathrm{mg} \mathrm{L}^{-1} \\
\text { For a } 100 \mathrm{MLD} \text { WTP: } \\
2500 \mathrm{~kg} \mathrm{day}^{-1}\end{array}$ & $\begin{array}{l}10 \mathrm{mg} \mathrm{L}^{-1} \\
\text { For a } 100 \mathrm{MLD}^{\mathrm{WTP}} \\
1000 \mathrm{~kg} \mathrm{day}^{-1}\end{array}$ \\
\hline $\begin{array}{l}\text { Estimated cost of coagulants in } \\
\text { WTP }\end{array}$ & $\begin{array}{c}\text { USD } 0.002 \mathrm{~m}^{-3} \\
\text { USD } 200.00 \text { day }^{-1} \\
\text { USD } 6,000.00 \text { month }^{-1}\end{array}$ & $\begin{array}{c}\text { USD } 0.11 \mathrm{~m}^{-3} \\
\text { USD } 11,000.00 \text { day }^{-1} \\
\text { USD } 330,000.00 \text { month }^{-1} \\
\end{array}$ \\
\hline Sludge & $\begin{array}{c}\text { Categorized as scheduled waste and has } \\
\text { to be treated before disposal }\end{array}$ & $\begin{array}{l}\text { Is not scheduled waste and considered } \\
\text { as environmentally harmless }\end{array}$ \\
\hline $\begin{array}{l}\text { Cost of sludge disposal } \\
\text { and treatment* }\end{array}$ & USD $684.00 \mathrm{MT}^{-1}$ & None \\
\hline Estimated sludge produced & $10 \mathrm{MT} \mathrm{month}^{-1}$ & $5 \mathrm{MT} \mathrm{month}^{-1}$ \\
\hline Estimated costs of sludge disposal & USD 6,835.00 month ${ }^{-1}$ & $\begin{array}{l}\text { None. } \\
\text { Sludge could instead be sold as organic } \\
\text { fertilizer for USD } 455 \text { month }^{-1} \text { at a market } \\
\text { value of USD 91.00 } \mathrm{MT}^{-1}\end{array}$ \\
\hline $\begin{array}{l}\text { Estimated monthly operating cost } \\
\text { of coagulant purchase and disposal }\end{array}$ & USD 13,000 & USD 330,000 \\
\hline Side effects & $\begin{array}{l}\text { Diseases related to excessive } \mathrm{Al}^{+} \text {residue in } \\
\text { treated water (Suarez-Fernandez et al.1999) }\end{array}$ & None \\
\hline
\end{tabular}

be used to treat raw water with heavy metal elements, thus providing an alternative to alum.

In this study, we also assessed the effect of $M$. oleifera bioflocculant toward bacterial abundance based on culture-dependent isolation on R2A, CGYA, TGYA, and MacConkey agars. The abundance of culturable bacteria decreased in every jar test analysis, and the percentage of reduction when bioflocculant was used ranged from $44 \%$ to $62 \%$ (Table 4 ). The percentage of reduction was strikingly lower than with alum, which reduced bacteria by $>99 \%(t=41.15, \mathrm{p}<0.001)$. There was also no discernible pattern in the percentage of reduction with increasing bioflocculant dosage. The average bacterial reduction on R2A, CGYA, TGYA, and MacConkey agars were $55 \pm 5 \%, 59 \pm 2 \%, 53 \pm 3 \%$, and $50 \pm 4 \%$, respectively. Although M. oleifera bioflocculant possesses bactericidal compounds that inhibit bacterial growth [22] - for example 4( $\alpha$-L-rhamnosyloxy)-benzyl isothiocynate [23] - the bacterial reduction was more likely due to the polypeptides in the bioflocculant as increasing dosage of the bioflocculant did not increase bacterial reduction. These polypeptides are known to coagulate particles and bacteria in the suspension [5], and might have already reached saturating conditions at a low bioflocculant dosage.

Although others have reported higher bacterial reduction (66\% to $93 \%$ ) with $M$. oleifera bioflocculant [11], the water sample used had low initial counts $(6 \mathrm{cfu}$ $\mathrm{ml}^{-1}$ to $100 \mathrm{cfu} \mathrm{ml}^{-1}$ ), which was about two orders lower than in this study. The water sample used in this study represented typical raw water used in drinking water treatment systems in Malaysia. Therefore, our results showed that one of the challenges for using $M$. oleifera bioflocculant was the residual bacterial counts, which were relatively higher than when using alum. Although the addition of second-stage sand filtration [11] or chlorination [24] can remove bacteria satisfactorily, further studies have to be carried out to confirm this.

\section{Economic Feasibility of $M$. oleifera Bioflocculant in Water Treatment System}

Although we had shown earlier that the production cost of the $M$. oleifera bioflocculant via SFE was lower than SE, we examined the economic feasibility on the use of $M$. oleifera bioflocculant versus alum in a conventional water treatment system (Table 5). In this study, the optimum dosage for water treatment using M. oleifera bioflocculant was $10 \mathrm{mg} \mathrm{L}^{-1}$, which was less than the amount of alum required $\left(25 \mathrm{mg} \mathrm{L}^{-1}\right)$. Similarly, the amount of sludge produced when using the bioflocculant was smaller and considered to be environmentally safe. In contrast, sludge produced from alum flocculation is categorized as scheduled waste, and disposal of this sludge incurs cost [25]. From Table 5, the estimated monthly operating cost of bioflocculant purchase and disposal for the $M$. oleifera bioflocculant was about 30 times higher than alum. Unlike alum that 
is widely available for water treatment plant operators worldwide, M. oleifera bioflocculant is currently only processed by vitamin and supplement manufacturers. Therefore, the current market price for M. oleifera bioflocculant is strikingly higher than alum. At current prices, the use of $M$. oleifera bioflocculant is untenable even though there is also a financially hidden cost in managing diseases related to excessive aluminiumion $\left(\mathrm{Al}^{3+}\right)$ residue in treated water [3]. If the production cost of $M$. oleifera bioflocculant can be reduced by an order, its estimated water treatment cost would only be about 2.5 times more, and this is probably more acceptable to the public since $M$. oleifera bioflocculant has shown itself to be capable of treating raw water and is environmentally friendly and safe toward human health.

\section{Conclusions}

In this study, the SFE method was a more efficient method in the production of $M$. oleifera bioflocculant than the SE method. More bioflocculant was extracted per weight of raw seeds, and the bioflocculant produced was smaller and more similar in size. Bioflocculant via SFE could reduce $>95 \%$ of turbidity and suspended solids, up to $60 \%$ bacterial abundance, and heavy metals. Apart from the higher residual bacterial abundance, bioflocculant performed as well as alum. Therefore, SFE showed promise in eliminating residual chemicals in bioflocculant preparation. At present, although $M$. oleifera bioflocculant has the potential to replace alum in water treatment plants, current prices must be reduced further to make it tenable.

\section{Acknowledgements}

Highest appreciation to the Public Service Department (JPA) of Malaysia for the scholarship that supported MAMY's post-graduate study (No. JPA (1)810729145883). The authors would also like to thank Kumpulan Air Selangor Sdn. Bhd. (KASSB), a local water treatment plant operator, for permission to enter Sg. Labu Water Treatment Plant and for supplying both water samples and information pertaining to operational costs. Gratitude is also extended to Malaysia's Ministry of Natural Resources and Environment (NRE) and the National Hydraulic Research Institute of Malaysia (NAHRIM) for supporting this study. LCW and BCW would also like to thank the Ministry of Higher Education for the $\mathrm{HiCoE}$ grant Phase II Fund (IOES-2014D).

\section{Conflict of Interest}

The authors declare no conflict of interest.

\section{References}

1. PENDERGAST M.M., HOEK E.M.V. A review of water treatment membrane nanotechnologies. Energy Environ. Sci. 4, 1946, 2011.

2. FARHAOUI M., DERRAZ M., Review on optimization of drinking water treatment process. J. Water Res. Prot. 8, 777, 2016.

3. WORLD HEALTH ORGANIZATION, Aluminium in drinking-water. Background document for development of WHO guidelines for drinking-water quality. World Health Organization, 2010.

4. JAMES C., O'MELIA C.R. Considering sludge production in the selection of coagulants. J. Am. Water Works Assoc. 74, 158, 1982.

5. OLADOJA N.A. Headway on natural polymeric coagulants in water and wastewater treatment operations. J. Water Process Eng. 6, 174, 2015.

6. MUYIBI S.A., EVISON L.M., Moringa oleifera seeds for softening hard water. Water Res. 29, 1099, 1995.

7. BARTH H., HABS M., KLUTE R., MULlER S., BERNARD T., Trinkwasseraufbereitung mit samen von Moringa oleifera Lam. Chemiker-Zeitung (Drinking Water Treatment with Moringa oleifera Seeds). Chemists News. 106, 75, 1982.

8. ALI E.N., MUYIBI S.A., SALLEH H.M., ALAM M.Z., SALLEH M.R.M., Production of natural coagulant from Moringa oleifera seed for application in treatment of low turbidity water. J. Water Resource Prot. 2, 259, 2010.

9. RUTTARATTANAMONGKOL K., SIEBENHANDLEHN S., SCHREINER M., PETRASCH A.M., Pilot-scale supercritical carbon dioxide extraction, physico-chemical properties and profile characterization of Moringa oleifera seed oil in comparison with conventional extraction methods. Ind. Crops Prod. 58, 68, 2014.

10. PIRAS A.R., FALCONIERI D., PORCEDDA S., DESSI M.A., MARONGIU B., Extraction of oil from wheat germ by supercritical $\mathrm{CO}_{2}$. Molecules 14, 2573, 2009.

11. PRITCHARD M., CRAVEN T., MKANDAWIRE T., EDMONDSON A.S., O'NEILL J.G., A comparison between $M$. oleifera and chemical coagulants in the purification of drinking water - An alternative sustainable solution for developing countries. Phys. Chem. Earth 35, 798, 2010.

12. URIBE J.A.R., PEREZ J.I.N., CAHUIL H.C., RUBIO G.R., ALCOCER C.G., Extraction of oil from chia seeds with supercritical $\mathrm{CO}_{2}$. J. Supercrit. Fluids 56, 174, 2011.

13. RICE E.W., BAIRD R.B., EATON A.D., Standard methods for the examination of water and wastewater, $23^{\text {rd }}$ ed. APHA, Washington, 2017.

14. PALAFOX J.O., NAVARRETE A., SACRAMENTORIVERO J.C., RUBIO-ATOCHE C., ESCOFFIE P.A., ROCHA-URIBE J.A., Extraction and characterization of oil from $M$. oleifera using supercritical $\mathrm{CO}_{2}$ and traditional solvents. Am. J. Analyt. Chem. 3, 946, 2012.

15. PAN S., ZHOU J., LI H., QUAN C., Particle formation by supercritical fluid extraction and expansion process. The Scientific World J. 2013, Article ID 538584, 6, 2013.

16. NDABIGENGESERA A., NARASIAH K.S., Quality of water treated by coagulation using Moringa oleifera seeds. Water Res. 32, 781, 1998.

17. IBAÑEZ E., HERRERO M., MENDIOLA J.A., CASTRO-PUYANA M., Extraction and characterization of bioactive compounds with health benefits from marine 
resources: Macro and micro algae, cyanobacteria, and invertebrates. In HAYES M. (ed.), Marine bioactive compounds: Sources, characterization and applications, Springer Science+Business Media, LLC, 55, 2012.

18. DIAZ-REINOSO B., MOURE A., DOMINGUEZ H., PARAJO J.C., Supercritical $\mathrm{CO}_{2}$ extraction and purification of compounds with antioxidant activity. J. Agric. Food Chem. 54, (7), 2441, 2006.

19. KATAYON S., MEGAT M.N.M.J., ASMA M., ABDUL GHANI L.A., THAMER A.M., AZNI I., AHMAD J., KHOR B.C., SULEYMAN A.M., Effects of storage conditions of Moringa oleifera seeds on its performance in coagulation. Biores. Technol. 97, 1455, 2006.

20. EMAN N.A., SULEYMAN A.M., HAMZAH M.S., ZAHANGIR MD.A., SALLEH M.R.M. Production of natural coagulant from Moringa oleifera seed for application in treatment of low turbidity water. J. Water Res. Prot. 2, 259, 2010.
21. AHO I.M., LAGASI, J.E. A new water treatment system using Moringa oleifera seed. Am. J. Sci. Ind. Res. 3, 487, 2012.

22. BUKAR A., UBA A., OYEYI T., Antimicrobial profile of Moringa oleifera Lam. extracts against some food - borne microorganisms. Bayero J. Pure Appl. Sci. 3, 43, 2010.

23. SUAREZ M., ENTENZA J.M., DOERRIES C., MEYER E., BOURQUIN L., SUTHERLAND J., MARISON I. MOREILLON P. MERMOD N. Expression of a plantderived peptide harboring water-cleaning and antimicrobial activities. Biotechnol. Bioeng. 81, (1), 13, 2003.

24. TCHOBANOGLOUS G., STENSEL H.D., TSUCHIHASHI R., BURTON F., ABU-ORF M., BOWDEN G., PFRANG W. Wastewater engineering, treatment and resource recovery, $5^{\text {th }}$ ed. McGraw-Hill Edu., New York, 2014.

25. CHEN P.J., WANG L.K., WANG M.S., HUNG Y., SHAMMAS N.K. Remediation of heavy metals in the environment. CRC Press, Boca Raton, FL, 2016. 